\title{
Forensic Investigation of a Database for Web Application
}

\author{
Hiral Patel, Dr. Ravi Sheth, Prof. Dharati Dholariya \\ School of Information Technology, Artificial Intelligence and Cyber Security Rashtriya Raksha University, \\ Gandhinagar, Gujarat, India
}

\begin{abstract}
Article Info

Volume 8, Issue 3

Page Number: 199-204

Publication Issue :

May-June-2021

\section{Article History}

Accepted :20May2021

Published:30May2021

Database Scientific Investigation(DBFI) includes the distinguishing proof, collection, conservation, remaking, examination, and detailing of database episodes. in any case, it may be a heterogeneous, complex, and vague field due to the assortment and multidimensional nature of database frameworks.Database measurable examination (DBFI)is an imperative region of inquiring about inside advanced forensics. Its significance is developing as advanced information gets to be more broad and commonplace. The challenges related to DBFI are various, and one of the challenges is the need for a harmonized DBFI handle for the examination to take after. This harmonized DBFI preparation has been created based on three key categories (i.e. arranging, arrangement, and pre- response, procurement and conservation and investigation, and reconstruction).

Keywords : Database Legal, Database Scientific Examination, Advanced Forensics.
\end{abstract}

\section{INTRODUCTION}

The utilize of distinctive phrasings in conjunction with diverse definitions to depict the same thing, question, or movement can cause disarray and uncertainty [1], which does not help reasoning in a court of law. An interesting phrasing at the side an explicit definition is more often than not required to advise the peruser on what each term within the handle show implied [2]. This is often especially valuable in advanced forensics where the uncertainty of terms seems to result in case disappointment [3]. Something else, the peruser may be within the dark about what the creator is considering and considering. Characterizing precisely what each wording implies proves inadmissibility in litigation[4]. Moreover, legitimate foes rejection. considering the unstable and energetic nature of computerized prove, particularly potential prove within the working memory of the drive, it is fundamental to extraordinarily indicate what each component involves, in an advanced legal prepare show. In this manner, a organized, organized, and bound together examination handle in a unique categorization is required to address the tall degree of excess, and equivocalness of the examination forms space agents. An add-up of 40 DBFI prepared models was looked into. We adjusted the plan science investigate method(DSRM) to classify and organize the repetitive and covering examination handle in this reviewed writing, based on the semantic likenesses in meaning or activites[5],[6]. All excess Examination forms that have comparative semantic 
meaning or utilitarian meaning are organized, blended, and gathered into an isolated category. Consequently, three categorizations, to be specific: i) arranging, arrangement, and pre-reaction category (PPPRC):

ii) Procurement and conservation category (APC), and iii) Examination and Remaking Cate-gory (Bend) are proposed. It acknowledges the harmonizations of the errands, exercises, and phrasings of all excess database scientific examination forms; in this manner, Tending to the heterogeneity and uncertainty of the examination forms among space agents.

\section{FORENSIC INVESTIGATION OF A WEB PETITION SECURITY ATTACK}

An effective scientific examination depends on a preparatory investigation stage and must follow a standard technique $4[7$,$] . Within the taking after$ subsections, we to begin with show the preparatory activities that ought to be considered towards a fruitful achievement of a web application measurable examination At that point, we show the step that ought to be streamed by a forensics agent to conduct an exhaustive investigation of the hacking endeavor. At long last, we outline how to arrange, advanced picture, and working frameworks forensics examination through the taking after preparatory activities are required for an effective forensics examination of a security attack on a web application [8]: Application forensics status: the internet application ought to

be well arranged for a scientific examination. Typically perhaps come to by Evidence collection: To get ready a web application for possible logging alternatives to gather the most extreme of computerized prove. On the off chance that the logging choices are cleared out at the default settings, the prove collection will be deficient and the application will not be prepared for a forensic investigation. Prove assurance: given that the log records will constitute the most source of advanced prove to perform a forensics examination, it is vital to secure these records to guarantee the astuteness of the information they contain, and consequently ensure the exactness of the advanced prove they give.

The following actions may be considered to protect the log files:

Setting the right authorization to the log files

- Keeping the log records out of the hacker's reach. This could be done by utilizing a few sorts of reinforcement utility, which can spare the log records on an inaccessible server.

- Utilizing a few sorts of checksum to confirm the log files integrity.Supportive legal: The forensics preparation of a web application guarantees the collection of the most extreme of advanced prove. But, it does not ensure the existence of all advanced prove required by a legal examination. Subsequently, steady legal devices ought to be utilized to assist the collection of the required computerized to prove that cannot be advertised by the logging alternatives of a web application. Computerized

Digital Computerized Advanced prove required to perform a legal examination of a web application security assault may be given by a organized or a working framework forensics device or by a third party advertising additional logging offices. More subtle elements almost web application strong measurable are displayed in segment IV. Legal examiner capacities: the forensics examiner should - Have a great understanding of web applications: engineering, components, expecting application stream, etc.

Have a great understanding of the security issues of web applications: vulnerabilities, security assault strategies, etc.

Well prepared for forensics investigation. Literature 


\section{Literature Survey}

In this paper, in this manner, we conduct a study of existing writing with the trust of understanding the body of work as of now fulfilled. Moreover, we construct on the existing writing to show a harmonized DBFI prepare utilizing plan science investigate technique. This harmonized DBFI handle has been created based on three key categories (i.e.arranging, planning and pre-response, procurement and conservation, and investigation and recreation) (Al- Dhaqm.,et.al.,2020.)

This thinks about think about all existing DBFI works, examine the issues and downsides of the DBFI field, and recommend a few arrangements for the found confinements and the DBFI field by displaying a wide writing survey that will help field analysts in comprehending DBFI which is the say within the table A few examination models have been proposed for the DBFI field by past analysts. In any case, the proposed models are specific and don't cover the whole DBFI field. For case, an examination prepare demonstration was proposed by[17,][18] to find data on the operations Investigation forms models. performed on an Oracle database. The SQL Server Measurable Investigation Technique was proposed by[2] to gather and analyze prove from MSSQL server databases. Database Scientific Examination Prepare Models: A Audit This strategy is comprised of four stages: examination planning, occurrence confirmation, artifact collection, and artifact examination. The Database Server Location Prepare Show was proposed by [19] to identify database servers and collect information(Al-Dhaqm., et.al.,2020.)

The proposed show comprises of five primary stages, a nitty-gritty rule show for advanced forensics; a Planning stage, Physical Forensics and Examination Stage, Computerized Forensics Stage, Announcing and Introduction Stage, and Closure Stage. In this show,nitty-gritty steps for each stage are given, so it can be utilized as direction for the legal agents, and it can help the advancement of modern investigative instruments and strategies (Abdalla, S, Hazem, S.et.al. 2007).

In the 2015 Second International Conference on Information Security and Cyber Forensics (InfoSec), This paper focuses on a lexicon attack experiment against WordPress (a web application) administered by a persona named Peter Quill (a fictitious character) The lexicon attack was able to with success guess the seven-character word used for the persona's user account. A group of techniques and tools area unit critically analyzed to see whether or not they will apply to the experiment state of affairs. The techniques largely target retrieving the log files from the online server, the application server, and also the net application itself, while the tools take care of assembling analyzing, and presenting the log file data information( Kyaw, A. K., Sioquim, F., \& Joseph, J. et.al 2015).

Advanced forensics is the science of procuring, recovering, protecting, and displaying information that has been prepared electronically and put away on advanced media. Computerized measurable science may be a generally modern teach that has the potential to incredibly influence particular sorts of examinations and arraignments. (Asian School of Cyber Laws 2006; Hall \& Wilbon 2005).

Within the 2015 Moment Universal Conference on Data Security and Cyber Forensics (Information Sec), This paper centers on a lexicon assault test against Word Press(a web application)managed by a persona named Dwindle Plume(an invented character). The word reference assault was able to effectively figure the seven-character watchword utilized for the persona's client account. A set of procedures and apparatuses are analyzed to decide whether they can 
apply to the explore situation. The procedures generally center on recovering the log records from the internet server, the application server, the database server, and the net application itself, whereas the apparatuses bargain with collecting, analyzing, and showing the log record information..( Lillis, D., Becker, B., O'Sullivan, T., \& Scanlon, M.et.al. 2016)

In this paper, they investigate the current challenges contributing to the excess in advanced forensics from a specialized point of view and diagrams a few futures investigate themes that seem significantly contribute to a more proficient advanced scientific handle. Given the ever- expanding predominance of innovation in advanced life, there's a corresponding increment within the probability of advanced gadgets being relevant to a criminal examination or respectful case..( Dubey, R., \& Gupta, H.et.al.2016).

They proposed a strategy that will be a combination of two security administrations for keeping up the secrecy, astuteness, and genuineness of information more proficiently. All the data related to things and their exchanges are put away in a database. But this database is profoundly inclined to SQL infusion assaults these days and their assaults have risen as a security risk to web applications and important data put away in a helpless database..(Rowlingson, R..2004)

\begin{tabular}{|c|c|c|c|c|}
\hline $\begin{array}{l}\text { Research } \\
\text { paper } \\
\text { Name }\end{array}$ & $\begin{array}{l}\text { Features } \\
\text { Extracted }\end{array}$ & $\begin{array}{l}\text { Classifier } \\
\text { used }\end{array}$ & $\begin{array}{l}\text { Dataset } \\
\text { used }\end{array}$ & $\begin{array}{l}\text { Limitati } \\
\text { on }\end{array}$ \\
\hline $\begin{array}{l}\text { Categoriz } \\
\text { ation and } \\
\text { organizati } \\
\text { on of } \\
\text { database } \\
\text { forensic } \\
\text { investigati } \\
\text { on } \\
\text { processes. }\end{array}$ & $\begin{array}{l}\text { Encourag } \\
\mathrm{e} \\
\text { arranged } \\
\text { an } \\
\text { examinat } \\
\text { ion of a } \\
\text { live } \\
\text { reaction } \\
\text { model } \\
\text { for } \\
\text { prophet } \\
\text { data that } \\
\text { comprise }\end{array}$ & $\begin{array}{l}\text { This paper } \\
\text { talks forms } \\
\text { which } \\
\text { made the } \\
\text { DBFI } \\
\text { recorded } \\
\text { vague } \\
\text { heterogene } \\
\text { ous us } \\
\text { among } \\
\text { space } \\
\text { investigates }\end{array}$ & & $\begin{array}{l}\text { The } \\
\text { propositi } \\
\text { on of a } \\
\text { bland } \\
\text { DBFI } \\
\text { prepare } \\
\text { /show } \\
\text { for the } \\
\text { DBFI } \\
\text { field. }\end{array}$ \\
\hline
\end{tabular}

\begin{tabular}{|c|c|c|c|c|}
\hline & $\begin{array}{l}\text { d of two } \\
\text { investiga } \\
\text { tion } \\
\text { process } \\
\text { distingui } \\
\text { shing } \\
\text { proof } \\
\text { prepare } \\
\text { and } \\
\text { verificati } \\
\text { on } \\
\text { collectio } \\
\mathrm{n} \text {. }\end{array}$ & & & \\
\hline $\begin{array}{l}\text { Database } \\
\text { forensic } \\
\text { investigati } \\
\text { on process } \\
\text { model: A } \\
\text { Review }\end{array}$ & $\begin{array}{l}\text { The } \\
\text { develop } \\
\text { ment of a } \\
\text { DBFI } \\
\text { store for } \\
\text { the } \\
\text { capacity } \\
\text { and } \\
\text { recovery } \\
\text { of DBFI } \\
\text { filed } \\
\text { informati } \\
\text { on. }\end{array}$ & $\begin{array}{l}\text { The } \\
\text { developme } \\
\text { nt of a } \\
\text { DBFI store } \\
\text { for the } \\
\text { capacity } \\
\text { and } \\
\text { recovery of } \\
\text { DBFI filed } \\
\text { information } \\
\text {. }\end{array}$ & $\begin{array}{l}\text { My sql } \\
\text { server } \\
\text { databas } \\
\text { e }\end{array}$ & $\begin{array}{l}\text { A } \\
\text { common } \\
\text { limitatio } \\
\mathrm{n} \text { of } \\
\text { DBFI } \\
\text { the } \\
\text { domain. } \\
\text { Redunda } \\
\text { nt and } \\
\text { irrelevan } \\
\text { t } \\
\text { investiga } \\
\text { tion } \\
\text { processe } \\
\text { s. }\end{array}$ \\
\hline $\begin{array}{l}\text { Guideline } \\
\text { model for } \\
\text { digital } \\
\text { forensic } \\
\text { investigati } \\
\text { on }\end{array}$ & $\begin{array}{l}\text { The } \\
\text { proposed } \\
\text { model } \\
\text { consists } \\
\text { of } 5 \text { main } \\
\text { phases, } \\
\text { the } \\
\text { preparati } \\
\text { on } \\
\text { section, } \\
\text { physical } \\
\text { forensic } \\
\text { and } \\
\text { investiga } \\
\text { tion } \\
\text { phase, } \\
\text { digital } \\
\text { forensics } \\
\text { phase, } \\
\text { reporting } \\
\text { presentat } \\
\text { ion } \\
\text { phase, } \\
\text { and } \\
\text { closure } \\
\text { phase. }\end{array}$ & $\begin{array}{l}\text { It is general } \\
\text { regarding } \\
\text { technology } \\
\text { so that it } \\
\text { will not be } \\
\text { restricted } \\
\text { to } \\
\text { technology } \\
\text { at the same } \\
\text { time it is } \\
\text { specific } \\
\text { enough so } \\
\text { that each } \\
\text { phase can } \\
\text { be } \\
\text { developed } \\
\text { in future } \\
\text { tools. }\end{array}$ & $\begin{array}{l}\text { Operati } \\
\text { ng } \\
\text { system } \\
\text { window } \\
\text { s. } \\
\text { UNIX, } \\
\text { and } \\
\text { Linux }\end{array}$ & $\begin{array}{l}\text { The } \\
\text { problem } \\
\text { of } \\
\text { cybercri } \\
\text { me is } \\
\text { increasin } \\
\text { g } \\
\text { rapidly, } \\
\text { which } \\
\text { needs a } \\
\text { rise } \\
\text { rapidly, } \\
\text { which } \\
\text { needs a } \\
\text { rise } \\
\text { requires } \\
\text { in the } \\
\text { digital } \\
\text { forensic } \\
\text { investiga } \\
\text { tion } \\
\text { space. } \\
\text { Alerting } \\
\text { the } \\
\text { integrity } \\
\text { of proof. }\end{array}$ \\
\hline $\begin{array}{l}\text { The } \\
\text { dictionary } \\
\text { attack on } \\
\text { wordpress } \\
\text { : security } \\
\text { and }\end{array}$ & $\begin{array}{l}\text { This } \\
\text { paper } \\
\text { focuses } \\
\text { on a } \\
\text { dictionar } \\
\text { y attack }\end{array}$ & $\begin{array}{l}\text { The } \\
\text { effective } \\
\text { forensic } \\
\text { investigatio } \\
\text { n of a } \\
\text { security }\end{array}$ & $\begin{array}{l}\text { Web } \\
\text { server, } \\
\text { applicat } \\
\text { ion } \\
\text { server, } \\
\text { Databas }\end{array}$ & $\begin{array}{l}\text { Redunda } \\
\text { nt and } \\
\text { irrelevan } \\
\mathrm{t} \\
\text { investiga } \\
\text { tion }\end{array}$ \\
\hline
\end{tabular}


Hiral Patelet al Int J Sci Res Sci Eng Technol, May-June-2021, 8 (3) : 199-204

\begin{tabular}{|c|c|c|c|c|}
\hline $\begin{array}{l}\text { forensic } \\
\text { analysis. }\end{array}$ & $\begin{array}{l}\text { experime } \\
\text { nt } \\
\text { Against } \\
\text { wordpres } \\
\text { s(a web } \\
\text { applicati } \\
\text { on) } \\
\text { administ } \\
\text { ered by a } \\
\text { persona } \\
\text { named } \\
\text { pater } \\
\text { Quill(a } \\
\text { fictitious } \\
\text { character }\end{array}$ & $\begin{array}{l}\text { attack on a } \\
\text { web } \\
\text { application } \\
\text { relies on } \\
\text { the forensic } \\
\text { readiness } \\
\text { of the web } \\
\text { application } \\
\text { system. }\end{array}$ & e server & $\begin{array}{l}\text { concepts } \\
\text { and } \\
\text { terminol } \\
\text { ogies. }\end{array}$ \\
\hline $\begin{array}{l}\text { Current } \\
\text { challenges } \\
\text { and future } \\
\text { research } \\
\text { Area for } \\
\text { digital } \\
\text { forensic } \\
\text { investigati } \\
\text { on }\end{array}$ & $\begin{array}{l}\text { They } \\
\text { proposed } \\
\text { and } \\
\text { validated } \\
\text { a new } \\
\text { approach } \\
\text { to target } \\
\text { acquisiti } \\
\text { on that } \\
\text { allow } \\
\text { file- } \\
\text { centric } \\
\text { process } \\
\text { wile not } \\
\text { disruptin } \\
\text { g } \\
\text { optimum } \\
\text { knowled } \\
\text { ge output }\end{array}$ & $\begin{array}{l}\text { In isolation } \\
\text { can hamper } \\
\text { the } \\
\text { discovery } \\
\text { of pertinent } \\
\text { information } \\
\text { for digital } \\
\text { investigator } \\
\text { and } \\
\text { detectives } \\
\text { concerned } \\
\text { multitude } \\
\text { of different } \\
\text { cases } \\
\text { requiring } \\
\text { digital } \\
\text { forensic } \\
\text { analysis. }\end{array}$ & $\begin{array}{l}\text { The } \\
\text { operatin } \\
\text { g } \\
\text { system } \\
\text { applicat } \\
\text { ion, } \\
\text { previou } \\
\text { sly } \\
\text { acquire } \\
\text { d non- } \\
\text { incrimin } \\
\text { ating } \\
\text { files. }\end{array}$ & $\begin{array}{l}\text { The } \\
\text { volume } \\
\text { problem, } \\
\text { resulting } \\
\text { from } \\
\text { increase } \\
\text { d storage } \\
\text { capacitie } \\
\text { s and the } \\
\text { number } \\
\text { of } \\
\text { devices } \\
\text { that store } \\
\text { informat } \\
\text { ion and a } \\
\text { lack of } \\
\text { sufficien } \\
\mathrm{t} \\
\text { automati } \\
\text { on for } \\
\text { analysis }\end{array}$ \\
\hline $\begin{array}{l}\text { SQL } \\
\text { Filtering } \\
\text { an } \\
\text { effective } \\
\text { technique } \\
\text { to prevent } \\
\text { sql } \\
\text { injection } \\
\text { attack }\end{array}$ & $\begin{array}{l}\text { We will } \\
\text { propose a } \\
\text { method } \\
\text { that may } \\
\text { be a } \\
\text { combinat } \\
\text { ion of } \\
\text { two } \\
\text { security } \\
\text { services } \\
\text { for } \\
\text { maintaini } \\
\text { ng } \\
\text { confident } \\
\text { iality , } \\
\text { integrity } \\
\text {, } \\
\text { authentic } \\
\text { ity of } \\
\text { data } \\
\text { more } \\
\text { efficientl } \\
\text { y }\end{array}$ & $\begin{array}{l}\text { The } \\
\text { database is } \\
\text { highly } \\
\text { prone to } \\
\text { SQLinjecti } \\
\text { on attacks } \\
\text { these days } \\
\text { and their } \\
\text { attacks } \\
\text { emerged as } \\
\text { a security } \\
\text { threat to } \\
\text { web } \\
\text { append } \\
\text { valuable } \\
\text { info stored } \\
\text { invulnerabl } \\
\text { e database. }\end{array}$ & $\begin{array}{l}\text { Sql } \\
\text { injectio } \\
n\end{array}$ & $\begin{array}{l}\text { All the } \\
\text { informat } \\
\text { ion } \\
\text { related } \\
\text { to items } \\
\text { and their } \\
\text { transacti } \\
\text { ons is } \\
\text { stored in } \\
\text { a } \\
\text { database. }\end{array}$ \\
\hline A ten-step & A wide & Wolfe- & Being & The \\
\hline
\end{tabular}

\begin{tabular}{|c|c|c|c|c|}
\hline $\begin{array}{l}\text { process } \\
\text { for } \\
\text { forensic } \\
\text { Readiness }\end{array}$ & $\begin{array}{l}\text { very of } \\
\text { workers } \\
\text { could get } \\
\text { entangle } \\
\text { d } \\
\text { investiga } \\
\text { tion and } \\
\text { will got } \\
\text { to } \\
\text { perceive } \\
\text { their } \\
\text { roles } \\
\text { within } \\
\text { it:it is not } \\
\text { just job } \\
\text { for the } \\
\text { forensic } \\
\text { investiga } \\
\text { tor or } \\
\text { system } \\
\text { managers }\end{array}$ & $\begin{array}{l}\text { Wilson and } \\
\text { Wolfe } \\
\text { discuss } \\
\text { manageme } \\
\text { nt } \\
\text { strategies } \\
\text { for } \\
\text { implementi } \\
\text { ng } \\
\text { forensics } \\
\text { security } \\
\text { measures }\end{array}$ & $\begin{array}{l}\text { ready to } \\
\text { collect } \\
\text { and use } \\
\text { proof } \\
\text { can also } \\
\text { have } \\
\text { profit as } \\
\text { a } \\
\text { deterren } \\
\text { t. }\end{array}$ & $\begin{array}{l}\text { problem } \\
\text { was } \\
\text { approach } \\
\text { ed from } \\
\text { the need } \\
\text { to cut } \\
\text { book the } \\
\text { time and } \\
\text { costs of } \\
\text { a } \\
\text { forensic } \\
\text { examinat } \\
\text { ion. }\end{array}$ \\
\hline
\end{tabular}

\section{RESEARCH PROBLEM}

How can be an abuse of cybercrime database scientificexaminationprovegatheringfromMySQLdata baseprove to collect my SQL database inquiry utilized withinthedatabaseconsentmySQLdatabase.

Theextricatedformswerecoveringandexcess. Hence, the categorization of these forms was connected, to fathomthe heterogeneity and uncertainty of these covering andrepetitive forms. In this way, the categorization strategydid not depend exclusively on naming conventions butrelied on similitudes within the exercises or meaning.Hence,threeprimarycategorizationshavebee nproposed in this think aboutwhich are PPPRC, APC,andBend.Eachcategoryincorporatescomparativee xercises,errands,implications, andpurposesnotwithstan dingthenamingofexaminationforms.

\section{FUTURE WORK}

THE FOLLOWING ARE A FEW IDEAS FOR FUTURE WORKSINTHEDBFIFIELD:

1) theproposalofagenericDBFIprocess/modelforthe DBFI field

2) thedevelopmentofaDBFIrepositoryforthestoragea ndretrievalofDBFI fieldknowledge. 
* Pre-Analysis

- Acquisition of database

- Database Architecture

- Database users \& Access

Investigation

- The integrity of Database \& data

- Database users Access controls

- Database users quarries

- Database procedures

- Database privileges misusage

- Control measures of the database server

* Reporting

- Database overview

- Database misconfiguration

- Database investigation workflow

- POC of analysis done

\section{CONCLUSION}

A add up to 40 DBFI prepare models were surveyed in this Prepare demonstrate analysts have utilized diverse approaches with diverse stages/phrases and wording. Most DBFI prepare models are particular and center on particular RDBMS occasions, so they as it were give low-level points of interest. Besides, none of the considered DBFI handle models can be called 'standardized'as each demonstrate encompasses a diverse point of view. This paper contributes to the DBFI field by displaying a wide writing audit that will help field analysts comprehending DBFI. This thinks about ponders all existing DBFI works talk about the issues and downsides of the DBFI field and propose a few arrangements for the found restrictions.

\section{REFERENCES}

[1]. Al-Durham, A., Abd Razak, S., Dampier, D. A., Choo, K. K. R., Siddique, K., Ikuesan, R. A., ... \& Kebande, V. R. (2020). Categorization and organization of database forensic investigation processes. IEEE Access, 8, 112846-112858.

[2]. Al-Durham, A., Abd Razak, S., Dampier, D. A., Choo, K. K. R., Siddique, K., Ikuesan, R. A., ... \& Kebande, V. R. (2020). Categorization and organization of database forensic investigation processes. IEEE Access, 8, 112846-112858.

[3]. Sunde, N., \& Dror, I. E. (2019). Cognitive and human factors in digital forensics: Problems, challenges, and the way forward. Digital Investigation, 29, 101-108.

[4]. A. Singh, A. R. Ikuesan, and H. S. Venter, "Digital forensic readiness framework for ransomware investigation," in Proc. Int. Conf. Digit. Forensics Cyber Crime. Midrand, South Africa: Springer, 2018, pp. 91_105.

[5]. S. R. Selamat, R. Yusof, and S. Sahib, "Mapping process of digital forensic investigation framework," Int. J. Comput. Sci. Netw. Secure., vol. 8, no. 10, pp. 163_169, 2008

[6]. Y. Yusoff, R. Ismail, and Z. Hassan, "Common phases of computer forensics investigation models," Int. J. Comput. Sci. Inf. Technol., vol. 3, no. 3, pp. 17_31, Jun. 2011.

[7]. Lazzez, A., \& Slimani, T. (2015). Forensics investigation of web application security attacks. Int. J. Comput. Netw. Inf. Secure, 7(3), 10-17.

[8]. Al-Dhaqm, A., Abd Razak, S., Othman, S. H., Ali, A., Ghaleb, F. A., Rosman, A. S., \& Marni, N. (2020). Database Forensic Investigation Process Models: A Review. IEEE Access, 8, 48477-48490.

[9]. David, A., Morris, S., \& Appleby-Thomas, G. (2020). A Two-Stage Model for Social Network Investigations in Digital Forensics. Journal of Digital Forensics, Security and Law, 15(2), 1.

[10]. S. Kelly and R. Pohjonen, "Worst practices for domain-speci_c modeling,"IEEE Softw., vol. 26, no. 4, pp. 22_29, Jul. 2009.

[11]. M. F. Caro, D. P. Josyula, M. T. Cox, and J. A. Jimenez, "Design and validation of a metamodel 
for metacognition support in arti_cial

intelligent systems," Biologically Inspired Cognit. Archit., vol. 9, pp. 82_104,Jul. 2014.

[12]. A. C. Bogen and D. A. Dampier,"Preparing for large-scale investigations with case domain modeling," in Proc. DFRWS, Aug. 2005, pp. $1 \_10$.

\section{Cite this article as :}

Hiral Patel, Dr. Ravi Sheth, Prof. Dharati Dholariya, "Forensic Investigation of a Database for Web Application", International Journal of Scientific Research in Science, Engineering and Technology (IJSRSET), Online ISSN : 2394-4099, Print ISSN : 2395-1990, Volume 8 Issue 3, pp. 199-204, May-June 2021. Available at doi : https://doi.org/10.32628/IJSRSET218326 Journal URL : https://ijsrset.com/IJSRSET218326 